\title{
HUMAN TRAFFICKING AND PROSTITUTION: BAND OF BROTHERS
}

\author{
by Louis Botha* \& Delene Strydom**
}

\section{Introduction and background}

On 14 December 2000 South Africa signed the UN Protocol to Prevent, Suppress and Punish Trafficking in Persons, especially Women and Children ('the Palermo Protocol'), and on 20 February 2004 ratified it. In so doing, South Africa committed itself to criminalising trafficking and developing legislation to combat it. On 3 October 2007 Essop Pahad, speaking at the Global Initiative to Counter Human Trafficking International Forum, said the National Prosecuting Authority had been tasked with coordinating this process and had formed an inter-sectoral task team to oversee the development of legislation. ${ }^{1}$ He further stated that provisions on trafficking had already been included in the Children's Bill ${ }^{2}$ and that the revised Sexual Offences Act would have a chapter dealing specifically with trafficking for sexual purposes.

On 16 December 2007 the Criminal Law (Sexual Offences and Related Matters) Amendment Act 32 of 2007 came into effect. It contains a chapter specifically dealing with trafficking as well as a section $^{3}$ specifically addressing the issue of trafficking for sexual purposes. Although these provisions ${ }^{4}$ are only temporary, ${ }^{5}$ as they are

* $\quad$ Final year BCom (Law) student, University of Pretoria.

** Final year BCom (Law) student, University of Pretoria.

1 http://www.info.gov.za/speeches/2007/07100316451002.htm (accessed 26 October 2009). Opening address by Essop Pahad, Minister in the Presidency, at the Global Initiative to Counter Human Trafficking International Forum Cape Town 3 October 2007; Also see sec 71 of Act 32 of 2007.

2 Now the Children's Act 38 of 2005 . These provisions are reflected in chapter 18 , secs 281-291. Sec 281(a) specifically states that one of the purposes of the provisions is 'to give effect to the UN Protocol to Prevent Trafficking in Persons'. Sec 282 also states that the Protocol enjoys the status of law in the Republic. However, the provisions of chapter 18 are not yet operational and will only come into effect on a date proclaimed in the Government Gazette. This is a rather disappointing state of affairs if one considers that the Bill had already been tabled in Parliament in 2003 as Bill 70B of 2003.

3 Sec 71

4 Secs $70-72$.

5 See the long title of Act 32 of 2007: 'Making interim provision relating to the trafficking in persons for sexual purposes.' Also see sec 70(1). 
not in full compliance with the Palermo Protocol, the South African government made an attempt to deal with the problem of trafficking, which up to that point had not been regulated by adequate legislation. In March 2009 Manto Tshabalala-Msimang, then Minister in the Presidency, stated that 'the process of translating South Africa's international commitments into national legislation is at an advance (sic) stage'.6

In 2008 government considered the idea of legalising prostitution for the duration of the 2010 FIFA World Cup. If prostitution were legalised, either for the duration of the World Cup or at any time thereafter, it would contradict the provisions of Part 6 of Act 32 of 2007 and nullify the work ${ }^{7}$ that has been done in an attempt to curb this crime of trafficking.

\section{Human trafficking in South Africa and the world}

The United Nations provides the following definition of human trafficking:

'Trafficking in persons' shall mean the recruitment, transportation, transfer, harbouring or receipt of persons, by means of the threat or use of force or other forms of coercion, of abduction, of fraud, of deception, of the abuse of power or of a position of vulnerability or of the giving or receiving of payments or benefits to achieve the consent of a person having control over another person, for the purpose of exploitation. Exploitation shall include, at a minimum, the exploitation of the prostitution of others or other forms of sexual exploitation, forced labour or services, slavery or practices similar to slavery, servitude or the removal of organs. ${ }^{8}$

This is an all inclusive definition found in the Palermo Protocol, the United Nations' action plan to combat trafficking. The Palermo Protocol sets out practical steps for countries to follow in their fight against human trafficking. All countries have been requested to sign this treaty and adhere to the suggestions made. Countries are then grouped into tiers according to their ability to meet the demands of the Palermo Protocol through legislation and other anti-trafficking activities. This official recognition of human trafficking has mobilised many government and NGO bodies to address this issue globally.

6 http://www.info.gov.za/speeches/2009/09032614151002.htm (accessed 26 October 2009). Address by Manto Tshabalala-Msimang, Minister in the Presidency, at the official launch of the Tsireledzani Conference: Towards an Integrated Human Trafficking National Action Plan, at Durban on 25 March 2009.

7 Specifically the abovementioned provisions in the Children's Act and Act 32 of 2007.

$8 \quad$ Art $3(\mathrm{a})$ of the Palermo Protocol. 
One of the main motivations for human traffickers is the promise of wealth in satisfying sexual demand. Human trafficking is regarded as the fastest growing organised crime after trading in drugs and guns, with an estimated market value of $\$ 32$ billion. ${ }^{9}$ International statistics have shown that there are at least 27 million victims of human trafficking currently in the world. This number grows by one million each year. $80 \%$ of victims are women and over $50 \%$ of victims are children. ${ }^{10}$

People are trafficked across country borders as well as within a country's borders. ${ }^{11}$ This makes trafficking difficult to detect, as border control only regulates transnational border entries and exits. Activities inside the borders often go unnoticed. This logistical problem necessitates additional indicators to alert authorities of the presence of human trafficking and prostitution has been an important indicator up to the present day.

Locally, Molo Songololo is one of the few NGO's that have done substantive research on human trafficking. Their findings, combined with the research of the South African government and the International Organisation on Migrations (IOM), are some of the limited sources of information available on human trafficking statistics in South Africa. This research has shown that between 28 000 and 30000 children are currently being prostituted in South Africa as a result of human trafficking. ${ }^{12}$ The US State Department also estimates that an additional 100000 people will be trafficked to South Africa during the 2010 FIFA World Cup. ${ }^{13}$ The magnitude of this problem necessitates action from our government to combat human trafficking.

\section{What South Africa has done in terms of the Palermo Protocol and the fight against human trafficking}

As already mentioned, South Africa ratified the Palermo Protocol in 2004, but until recently has battled to meet the requirements thereof. According to the United Nations report on South Africa's progress, the country has failed to meet the Palermo Protocol

October 2009).

http://www.notforsalecampaign.org/about/slavery/\#rs_2 (accessed 17 October 2009); http://www.endhumantraffickingnow.com/Ābout_human_trafficking/ Pages/Facts_figures.aspx (accessed 17 October 2009).

11 http://www.stopthetraffik.org/humantrafficking/problem.aspx (accessed 3 October 2009).

12 M Songololo The trafficking of children for purposes of sexual exploitation (2000) 30.

13 http://www.justiceacts.org/1.html (accessed 7 August 2008). 
requirements for four consecutive years since 2004. This does not necessarily mean that nothing was done about the problem; it merely highlights the fact that any investigations or advances in this area of criminal law have not been properly documented or reported. This has created the impression that South Africa's signing of the protocol merely had symbolic value. Fortunately, the necessary antitrafficking legislation has recently been implemented and thus eliminated this impression. The report also stated that the South African government has opened prosecutions against 16 suspected trafficking offenders. ${ }^{14}$

Before the enactment of the Children's Act ${ }^{15}$ and Act 32 of 2007 , no legal definition for human trafficking existed in South African law. ${ }^{16}$ This meant that a trafficker could be found guilty of a number of crimes related to trafficking, such as abduction or running a brothel, but not for the crime of trafficking itself. This problem has been addressed, but the possibility of legalising prostitution looms on the horizon and it is believed that this new development threatens to trample any progress made in the fight against human trafficking.

\section{The current position of the South African law on prostitution}

Although the issue of legalising prostitution and its justification has recently again been seriously considered by the South African government, the Constitutional Court has already expressed its opinion on its legalisation in the case of Jordan and Others $v S$ and Others. ${ }^{17}$ The facts of the case are as follows: ${ }^{18}$ The appellants, a brothel-owner, a brothel employee and a prostitute, had been convicted in a magistrate's court of contravening the Sexual Offences Act 23 of 1957 . They subsequently appealed to the High Court, ${ }^{19}$ challenging only the constitutionality of sections 2, 3(b) and (c) and $20(1)(a A)$ of Act 23 of 1957. They did not dispute the fact that they had violated the impugned provisions. 20 The High Court upheld the convictions of the first two appellants, ${ }^{21}$ but set aside the conviction

14 United States State Department 'Report on trafficking in persons' (2009).

Act 38 of 2005.

Secs 281-291 of Act 38 of 2005; Secs 70-72 of Act 32 of 2007.

200211 BCLR 1117 (CC).

S v Jordan and Others 200110 BCLR 1055 (T); also (n 16 above) 1117.

As above.

As above.

They contravened sections 2, 3(b) and (c) of the Sexual Offences Act 23 of 1957. 
and sentence of the third appellant, based on the fact that section 20(1)(aA) of Act 23 of 1957 was unconstitutional. ${ }^{22}$ The High Court failed to indicate which sections of the Constitution had been violated by section $20(1)(\mathrm{aA})$, or why the violation could not be justified. ${ }^{23}$

Although the Constitutional Court decided the case based on the provisions of the Interim Constitution ${ }^{24}$ as this was the Constitution that was in force when the events that gave rise to these proceedings occurred, ${ }^{25}$ there is no material difference between the provisions of section 8 of the Interim Constitution and section 9 of the Final Constitution, ${ }^{26}$ both of which deal with discrimination. ${ }^{27}$ Thus the case retains its relevance within the South African system of judicial precedence. The appellants challenged the constitutionality of section 20(1)(aA) of Act 23 of 1957, mainly on the ground that the section unfairly discriminated against women. ${ }^{28}$

The majority of the Constitutional Court, per Ncgobo J, rejected this argument based on its interpretation of the section, stating that the words 'any person' as they are found in section 20, meant that the section penalises any person who engages in sex for reward. ${ }^{29}$ Thus the section was gender-neutral and did not discriminate directly based on gender. ${ }^{30}$ The majority went further by saying that the section did not amount to indirect discrimination either purely because it distinguished between the prostitute and the consumer because such a differentiation between the dealer and consumer is a common distinction found in a number of statutes. ${ }^{31}$ The majority further states that the purpose of the section is the outlawing of

$S v$ Jordan (n 18 above). The High Court explained that section 20(1)(aA) of Act 23 of 1957 amounted to 'obviously unjustified discrimination between not only sexes but also persons' at 1058A of the judgment. It also found that the impugned provision was discriminatory by distinguishing between 'a prostitute who received money for her favours and her sister who receives, for rendering similar services, a benefit or reward of a different kind such as a paid holiday weekend...' at $800 \mathrm{H}$.

$S \vee$ Jordan (n 18 above) para 6.

Interim Constitution of the Rebuplic of South Africa Act 200 of 1993

$S \vee$ Jordan (n 18 above) para 3.

Constitution of the Republic of South Africa, 1996.

$S \vee$ Jordan (n 18 above) para 4.

$S v$ Jordan (n 18 above) para 8.

$S \vee$ Jordan (n 18 above) para 9.

As above.

$S \vee$ Jordan (n 18 above) para 10. The Court here refers to the following legislation: Section 3(3) of the Dangerous Weapons Act 71 of 1968; section 47(f) of the Sea Fishery Act 12 of 1988; section 159(e), 160(b) and 161(c) of the Liquor Act 27 of 1989; and section 18(1) read with section 29(b) of the Medicines and Related Substances Act 101 of 1965. The Court then proceeds to explain in paragraph 11, that the differentiation made by section $20(1)(\mathrm{aA})$ must be viewed against the fact that a male or female consumer is in fact also guilty of committing an offence under the common law and also liable to the same punishment as the prostitute, citing $R \vee$ Jackelson 1920 AD 486490 and S v Kellner 19632 SA 435 (A) 446G-447G as its authority. The consumer is also guilty of committing an offence in terms of Section 18(2) of the Riotous Assemblies Act 17 of 1956. 
commercial sex and it can be curbed by striking the prostitute by means of criminal sanctions. 32

The Court then proceeded to explain that if there is discrimination based on gender, it can hardly be said to be unfair as Act 23 of 1957 pursues an important and legitimate constitutional purpose, namely, to outlaw commercial sex. ${ }^{33}$ Furthermore, both the consumer and the prostitute are criminally liable under different statutes, as explained above, and thus, if there is any discrimination, it cannot be said to be unfair. ${ }^{34}$ The Court also stated that the social stigma attached to prostitutes is there because of their conduct and not their gender, as they choose to engage in commercial sex, thereby knowingly accepting the risk that their standing in the community could decline. ${ }^{35}$ Thus if discrimination had taken place based on gender, it is not unfair.

The aforementioned provisions of Act 23 of 1957 were also challenged based on the appellants' right to economic activity, in terms of section 26 of the Interim Constitution and the right to privacy. ${ }^{36}$

With regard to the violation of the appellants' right to economic activity which is protected in the right to freedom of trade, occupation and profession in the Final Constitution, ${ }^{37}$ the majority found that no such violation had taken place. Although section 26(1) prohibits the infringement of a person's economic activity, section 26(2) allows such an infringement if the legislation limiting the right has a legitimate purpose and the prohibition it entails is sanctioned by section $26(2) .38$ The court acknowledged that prostitution is associated with violence, drug abuse and child trafficking ${ }^{39}$ and that measures (referring to sections 2, 3 and 20 of Act 23 of 1957) intended to eliminate the harmful effects of prostitution and brothel-keeping, are clearly measures designed to protect and improve the quality of life $^{40}$ which fall within the ambit of section $26(2)$. This notion was reiterated by the Labour Court in the more recent case of 'Kylie' $v$ CCMA \& others. ${ }^{41}$ The court went further in this instance by stating that the Act is aimed at preventing trafficking in general and at preventing the spread of sexually transmitted diseases. ${ }^{42}$

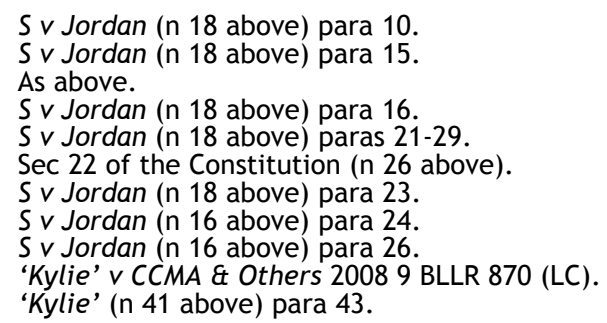


The challenge of the appellants in $S v$ Jordan based on their right to privacy was dismissed as a person who commits a crime in private (such as prostitution), the nature of which can only be committed in private, cannot necessarily claim the protection of the privacy clause especially because the law should be equally concerned with crimes that are committed in public and those committed in private. ${ }^{43}$ In actual fact, the issue of privacy does not lie at the inner core of the matter, but rather the prohibition imposed on prostitutes, which means that they cannot sell their sexual services. ${ }^{44}$

It should be noted that even the Constitutional Court is divided on the matter of section 20(1)(aA)'s constitutionality - 6 of the 11 judges believed it to be constitutional (and prostitution thus illegal), whereas the minority of 5 believed it to be unconstitutional (and prostitution thus legal). However, as the majority judgement is binding authority, prostitution is currently illegal in South African law.

\section{Legalising prostitution}

There are two separate arguments relating to the legalisation of prostitution. Firstly, there should be a move away from the idea that most prostitutes join the commercial sex industry willingly. Secondly, from a crime control perspective, one cannot view prostitution and human trafficking as separate phenomena. Prostitution fuels human trafficking and vice versa. These contentions are discussed below.

\subsection{The implications of prostitution and the unwillingness of participants to enter the industry}

Certain prominent figures in South African society have promoted the legalisation of prostitution. Jackie Selebi, the former National Police Commissioner, who is currently standing trial on charges of corruption and defeating the ends of justice, is one of the forerunners in the the promotion of the legalising prostitution. His focus is on satisfying the 'sex buying men' and not helping the sex worker. ${ }^{45}$ George Lekgheto, ANC Member of Parliament has said that you hear about rape cases so often because people do not have access to sex workers. He also believes that it would create more taxable income and lower South Africa's unemployment statistics if prostitution were legalised. 46 These statements seem relevant from an economic point of view and the current economic crisis also serves as a powerful motivation to

$S \vee$ Jordan (n 18 above), para 28.

$S \vee$ Jordan (n 18 above), para 29.

A Mhlongo \& M Langa '2010: Sex, booze and soccer' Cape times 7 April 2007.

http://news.bbc.co.uk/2/hi/africa/7215962.stm (accessed 18 October 2009). 
consider additional sources of income, but these statements merely represent one side of the argument.

The assumption that people choose to be involved in prostitution creates a false idea of the commercial sex industry, as $89 \%$ of women currently in prostitution want to leave the industry. ${ }^{47}$ Keeping this in mind, combined with the profound physical and psychological effects of prostitution, a clear constitutional dilemma starts to emerge. The legal system in South Africa is governed by a supreme constitution ${ }^{48}$ in which the human rights of people are paramount, although they can be limited. ${ }^{49}$ A strong South African economy is an ideal that appeals to all citizens, but economic stimulation cannot take place at the expense of human rights. Protection of vulnerable groups is one of the main aims of the South African legal system. ${ }^{50}$ The South African Constitution is founded on values that promote the acknowledgment and protection of the inherent worth of every person and these objectives are clearly communicated throughout the Constitution. ${ }^{51}$

Several constitutional rights may be infringed by allowing prostitution; the most prominent of these being the right to human dignity, ${ }^{52}$ security of the person ${ }^{53}$ and, in cases where prostitutes are killed, the right to life. ${ }^{54}$ One can also argue that allowing prostitution infringes on the right not to be subjected to slavery, servitude or forced labour. ${ }^{55}$ Although a minority of people enter the commercial sex industry of their own volition and want this trade to be recognised as a profession in its own right, there is still a belief that the constitutional right to freedom of trade, occupation and profession ${ }^{56}$ cannot be regarded as more important than the other rights entrenched in the Bill of Rights in this instance.

Section 36 of the Constitution allows for the limitation of a right in the Bill of Rights by a law of general application, as long as the limitation is reasonable and justifiable in an open and democratic

$M$ Farley 'Prostitution and trafficking in nine countries: an update on violence and post-traumatic stress disorder' (2003) 2 Journal of Trauma Practice 33.

48 Sec 2 of the Constitution.

$49 \mathrm{Sec} 36$ of the Constitution.

50 Manto Tshabalala Msimang, in her capacity as Minister in the Presidency, stated in March 2009 that the key is ensuring protection of all in South Africa in a way that 'prioritises' the most vulnerable members of our society. In this respect it should also be noted that special protection is afforded to children in terms of section 28 of the Constitution. South Africa has also ratified the Convention on the Elimination of All Forms of Discrimination against Women on 15 December 1995, which means that when interpreting the Bill of Rights, especially in the context of women's rights, this treaty must be taken into account in terms of sec 39(1)(b) of the Constitution.

51 Preamble and sec 1 of the Constitution.

52 Sec 10 of the Constitution.

53 Sec 12 of the Constitution.

54 Sec 11 of the Constitution.

55 Sec 13 of the Constitution.

56 Sec 22 of the Constitution. 
society based on human dignity, equality and freedom. Certain factors are also listed in this section, according to which one can determine if the limitation is justified. The nature of the abovementioned infringed rights is central to human dignity and freedom. As the Constitutional Court stated in $S v$ Jordan, from the nature of the statements of certain high-ranking officials, the purpose of the limitation would be to support the economy, lower statistical crime rates and to satisfy the local and international demand for commercial sex. ${ }^{57}$ The nature and extent of these limitations will be vast, since prostitutes who are not doing it of their own volition will not be protected by the legality of their trade. Legalising prostitution is thus not the answer to a battling economy or high crime rates these problems must be addressed through different means. If prostitution is not legalised South Africa might not be able to meet the demand for a commercial sex industry, but this is a small price to pay for the protection of the human rights of its citizens.

The following statistics provide an indication of the effects of prostitution and serves as the basis for the contention that the allowance of prostitution infringes on basic human rights: $60-75 \%$ of women involved in prostitution were raped. $70-95 \%$ of women were physically assaulted and $68 \%$ revealed symptoms of post traumatic stress at the levels which are usually found in war veterans and survivors of organised torture. ${ }^{58}$ Without elaboration on the health issues surrounding prostitution, the fact remains that $70.4 \%$ of women in prostitution in South Africa are infected with HIV. ${ }^{59}$

In $S \vee$ Jordan the state advanced various reasons before the Constitutional Court for the suppression of commercialised sex. Firstly, the business is said to breed crime that is not confined to the sale of sex but extends into violent crimes. Secondly, the business results in the exploitation of women and children. Thirdly, it leads to trafficking in children. Fourthly, it leads to the spread of sexually transmitted diseases. With the government's current inability to keep crime under control and the provisions prohibiting trafficking of people and children in the Children's Act and the Criminal Law (Sexual Offences and Related Matters) Amendment Act, the state will be acting contrary to its own interests by legalising prostitution. It is highly unlikely that the government will be able to deal with the effects of legalising prostitution considering its current inability in dealing with these problems, not to mention the effect it will have on the HIV-infection rate, South Africa's rate currently being the highest in the world.

58 n 45 above.

R Ramsay 'Psychiatric morbidity in survivors of organised state violence including torture' (1993) British Journal of Psychiatry 155-59; Farley (n 47 above).

59 http://www.christianaction.org.za/articles/whyprostitutionnotdecrim.htm (accessed 3 August 2009). 


\subsection{The link between human trafficking and prostitution}

As previously stated, prostitution and human trafficking are interlinked criminal activities. The United States government adopted a strong position against legalised prostitution in the December 2002 National Security Presidential Directive, based on evidence that prostitution is inherently harmful and dehumanising and fuels trafficking in persons. This report also states directly that 'where prostitution is legalised or tolerated there is a greater demand for human trafficking victims and nearly always an increase in the number of women and children trafficked in commercial sex slavery. ${ }^{60}$ These sentiments are also echoed by the research of Donna M Hughes, Professor at the University of Rhode Island. She states that 'countries that have legalised prostitution in order to regulate it are still faced with serious problems of sex trafficking. ${ }^{, 61}$

It is also relevant that one of the recommendations from the United Nations Report was that government must support NGO initiatives that try to limit the demand for commercial sex. ${ }^{62}$ This recommendation cannot be ignored and it can be deduced that legalising prostitution will undermine it.

The United Nations categorises countries according to the extent with which they comply the requirements of the Palermo Protocol in an annual report. Countries are ranked in one of the following four categories: Tier 1, Tier 2, Tier 2 watch list, and Tier 3 . Tier 1 countries are those that fully meet the requirements of the Palermo Protocol and Tier 3 those countries that do not meet the requirements at all. Tables 1 and 2 indicate the correlation between several countries' prostitution policies and how they have been ranked according to the report.

All the countries that have legalised prostitution either fully or in part fall into Tier 1 , Tier 2 , and the Tier 2 watch list. The only country that has legalised prostitution and falls into Tier 3 is Malaysia. The rest of these countries already have strong anti-trafficking legislation in place, or are in the process of implementing it. From this it appears that the legalisation of prostitution created a more urgent need to prevent and combat human trafficking.

The opposite is true for countries in which prostitution is illegal. These countries fall into the Tier 2 , Tier 2 watch list, and Tier 3. These countries are not that far advanced in implementing antitrafficking legislation. There could be numerous reasons for this. Most of these are developing nations. This may have a direct influence on

60 www.state.gov/documents/organisation/38901.pdf (accessed 17 October 2009).

61 http://www.uri.edu/artsci/wms/hughes/germany_world_cup.doc (accessed 18

62

October 2009).

n 14 above. 
the effectiveness of implementing legislation or managing a crime problem. Still, the comparison reveals that not one country in which prostitution is illegal has yet implemented strict anti-trafficking legislation.

Sex trafficking would not exist without the demand for commercial sex, and it is this demand that traffickers try to satisfy. If the sexual motivation could be taken out of trafficking, a significant part of the trafficking industry would diminish since $80 \%$ of people being trafficked are women and children, and they are mostly used for sex work. ${ }^{63}$ The Swedish government stated that human trafficking would not survive if it is not upheld by local prostitution markets where men are willing and able to buy women and children. In addition, the government stated that where there is legal prostitution, local governments must find ways to address flourishing sex trafficking markets. ${ }^{64}$

It is difficult to identify traffickers in a system where prostitution is legal. Women who are lured into trafficking often enter a country legally. By the time a woman reaches her destination she is already in the trafficking system and working as a forced prostitute. It will be very difficult to get her out of this situation if prostitution is legal. The effectiveness of anti-trafficking measures and legislation will be significantly decreased by legalising prostitution. Prostitution is often the only visible sign of trafficking and sometimes the only link that can be established between victims of trafficking and trafficking syndicates. Minors who participate in this industry with false identification provided by their traffickers will also be a big concern. South Africa's well-drafted Children's Act that prohibits the trafficking of children ${ }^{65}$ will be of limited use in the face of legal prostitution.

\section{Conclusion}

It has been argued that the legalisation of prostitution would fuel human trafficking across the world. South Africa's jurisprudence also reflects that the outlawing of prostitution is not unconstitutional and constitutes a justifiable limitation of the rights to equality, privacy and to economic activity (which is protected in the right to freedom of trade, occupation and profession in the Final Constitution). South Africa has implemented new anti-human trafficking legislation recently. However by legalising prostitution, it will become very difficult to protect the vulnerable groups, most notably women and

63

August 2008

65 Secs 281-291 of Act 38 of 2005. 
children, in South African society from becoming victims of this crime. Government has acknowledged that prostitution breeds violent crimes, results in the exploitation of women and children, leads to trafficking in children and the spread of sexually transmitted diseases. Considering that these are some of the biggest problems society faces today and that government has not been able to address these problems sufficiently, a huge injustice will be done to society and the prostitutes themselves, most of whom are not in the industry of their own volition.

\section{Table 1}

\begin{tabular}{|c|c|c|c|c|}
\hline \multicolumn{2}{|c|}{$\begin{array}{l}\text { Countries with legalised or } \\
\text { semi-legal prostitution }\end{array}$} & \multicolumn{3}{|c|}{ Human trafficking legislation rankings } \\
\hline & & Tier 1 & Tier 2 & Tier 2 watch \\
\hline $\begin{array}{l}\text { Argentina } \\
\text { Australia } \\
\text { Belgium } \\
\text { Brazil } \\
\text { Canada } \\
\text { Colombia } \\
\text { Costa Rica } \\
\text { Czech } \\
\text { Republic } \\
\text { Denmark } \\
\text { Estonia } \\
\text { Ethiopia } \\
\text { Finland } \\
\text { France } \\
\text { Germany } \\
\text { Greece } \\
\text { Guatemala } \\
\text { Israel } \\
\text { Italy }\end{array}$ & $\begin{array}{l}\text { Japan } \\
\text { Kyrgyzstan } \\
\text { Latvia } \\
\text { Mexico } \\
\text { Netherlands } \\
\text { New Zealand } \\
\text { Norway } \\
\text { Peru } \\
\text { Senegal } \\
\text { Sweden } \\
\text { Singapore } \\
\text { Slovakia } \\
\text { Spain } \\
\text { Switzerland } \\
\text { Turkey } \\
\text { UK } \\
\text { Armenia } \\
\text { Bulgaria } \\
\text { Uruguay }\end{array}$ & $\begin{array}{l}\text { Australia } \\
\text { Austria } \\
\text { Belgium } \\
\text { Canada } \\
\text { Colombia } \\
\text { Czech } \\
\text { Republic } \\
\text { Denmark } \\
\text { Finland } \\
\text { France } \\
\text { Germany } \\
\text { Italy } \\
\text { Lithuania } \\
\text { Luxembourg } \\
\text { Macedonia } \\
\text { Mauritius } \\
\text { Netherlands } \\
\text { New } \\
\text { Zealand } \\
\text { Nigeria } \\
\text { Norway } \\
\text { Poland } \\
\text { Slovenia } \\
\text { Spain } \\
\text { Sweden } \\
\text { Switzerland } \\
\text { UK }\end{array}$ & $\begin{array}{l}\text { Brazil } \\
\text { Greece } \\
\text { Estonia } \\
\text { Ethiopia } \\
\text { Singapore } \\
\text { Slovakia } \\
\text { Turkey } \\
\text { Israel } \\
\text { Japan } \\
\text { Kyrgyzstan } \\
\text { Latvia } \\
\text { Mexico } \\
\text { Peru Senegal } \\
\text { Armenia } \\
\text { Bulgaria } \\
\text { Uruguay }\end{array}$ & $\begin{array}{l}\text { Argentina } \\
\text { Guatemala } \\
\text { Costa Rica }\end{array}$ \\
\hline
\end{tabular}




\section{Table 2}

\begin{tabular}{|c|c|c|c|c|}
\hline \multicolumn{2}{|c|}{$\begin{array}{l}\text { Countries where } \\
\text { prostitution is illegal }\end{array}$} & \multicolumn{3}{|c|}{ Human trafficking legislation rankings } \\
\hline Afghanistan & Kenya & Tier 2 & Tier 2 watch & Tier 3 \\
\hline $\begin{array}{l}\text { Angola } \\
\text { Bahamas } \\
\text { Barbados } \\
\text { Cambodia } \\
\text { China } \\
\text { Cuba } \\
\text { Dominica } \\
\text { Egypt } \\
\text { Guyana } \\
\text { India } \\
\text { Iran } \\
\text { Iraq } \\
\text { Jamaica }\end{array}$ & $\begin{array}{l}\text { North Korea } \\
\text { Philippines } \\
\text { Romania } \\
\text { Rwanda } \\
\text { Saudi Arabia } \\
\text { South Africa } \\
\text { Taiwan } \\
\text { Thailand } \\
\text { Uganda } \\
\text { United Arab } \\
\text { Emirates }\end{array}$ & $\begin{array}{l}\text { Afghanistan } \\
\text { Albania } \\
\text { Bahamas } \\
\text { Barbados } \\
\text { Jamaica } \\
\text { Kenya } \\
\text { Liberia } \\
\text { Romania } \\
\text { Rwanda } \\
\text { Taiwan } \\
\text { Thailand } \\
\text { Uganda } \\
\text { South Africa }\end{array}$ & $\begin{array}{l}\text { Angola } \\
\text { Cambodia } \\
\text { Cuba } \\
\text { Dominica } \\
\text { Egypt } \\
\text { Guyana } \\
\text { India } \\
\text { Iraq } \\
\text { Philippines } \\
\text { United Arab } \\
\text { Emirates }\end{array}$ & $\begin{array}{l}\text { China } \\
\text { Egypt } \\
\text { Iran } \\
\text { Saudi Arabia } \\
\text { North Korea }\end{array}$ \\
\hline
\end{tabular}

